\title{
GERAKAN MAHASISWA DALAM KEMELUT POLITIK DI MYANMAR: PERGULATAN MEWUJUDKAN KEBEBASAN
}

\author{
Oleh: Mohammad Maiwan*
}

\begin{abstract}
The dynamic of the student movement in Myanmar influenced by social and political factors. The emergence of their movement as a direct response of the condition of the nation. In the past involvement of student leaders in various organizations provide an important contribution to the emergence of anti-colonial movement, which culminated in independence in 1948. After independence student movement emerged as a moral force in correct of government policies. From the reign U Nu liberal democracy in 1948-1958, 1960-1962, and then under the military regime in 1958-1960 and 1962-2011, until under quasi-military rule today. The existence of differences between student and regime causes their had clashed and suppressed in 1958, 1962, 1974, 1975, 1988. At a certain stage, their movement give a pressure on the regime.
\end{abstract}

Key Words: Student, movement, politics.

\section{Pendahuluan}

Golongan mahasiswa merupakan salah satu komponen penting dalam kehidupan masyarakat di negara berkembang. Kedudukan mereka mengisi ruang kekosongan pada lapisan terdidik karena minimnya tingkat pendidikan sebagian besar warganya. Sebagai golongan muda terdidik kalangan mahasiswa kerapkali paling kedap dengan isu-isu yang menyangkut aspek perubahan. Berbeda dengan golongan tua yang lebih mapan, para mahasiswa dengan kesadaran intelektualnya akan selalu gelisah dalam menatap persoalan di sekitarnya, terutama persoalan-persoalan politik. Konteks masyarakat berkembang yang berada dalam tahap transisional serta desakan situasi menjadi lahan subur tempat bersemainya ide-ide revolusioner mahasiswa, sekaligus sumber inspirasi bagi perjuangan mereka. Karena itu, tidaklah mengherankan jika di banyak negara berkembang kalangan mahasiswa seringkali menjadi kekuatan pelopor dalam mencetuskan perubahan sosial dan mendorong perubahan politik (Altbach 1988:1-18).

Dalam prakteknya, ide-ide mahasiswa yang bertitik tolak dari logika idealisme dan segi-segi normatif seringkali bertolak belakang dengan jalan pikiran dan arus umum yang berlaku dalam masyarakat. Bahkan dalam beberapa aspek, idealismenya justru bertabrakan dengan kepentingan jangka pendek kelompok dominan dan pro kemapanan. Tindakan mereka seringkali menjadi ancaman bagi

\footnotetext{
* Dosen Prodi Pendidikan Pancasila dan Kewarganegaraan Jurusan Ilmu Sosial Politik Fakultas Ilmu Sosial Universitas Negeri Jakarta
} 
$40 \quad \begin{aligned} & \text { JURNAL ILMIAH MIMBAR DEMOKRASI } \\ & \text { VOLUME 13, NOMOR 2, APRIL } 2014\end{aligned}$

kelompok yang berkuasa dan pada tahap tertentu secara ironis justru menjadi tumbal bagi tegaknya suatu rejim politik.

Salah satu negara berkembang yang menorehkan catatan penting, yang cukup sarat dengan perjuangan mahasiswa adalah Myanmar (dulu Burma). Sejak awal lagi, bahkan sebelum mencapai kemerdekaan, sejarah Myanmar mencatat bagaimana golongan mahasiswa secara intensif terlibat dalam perjuangan pembebasan bangsa dan kemudian dalam penentangan terhadap kekuasaan rejim domestik sesudah merdeka. Gerakan mahasiswa di Myanmar mengalami pasang surut perjuangan dan terlibat dalam berbagai kemelut politik yang begitu panjang sehingga hari ini. Bertitik tolak dari realitas tersebut artikel ini berusaha untuk menjelaskan lebih jauh tentang bagaimana latar belakang dan perkembangan gerakan mahasiswa di Myanmar selama ini? Apa bentuk-bentuk perlawanan yang mereka lakukan, bagaimana respon rejim terhadapnya, serta sejauh mana ketahanan gerakan mereka? Penjelasan atas pertanyaan-pertanyaan tersebut dapat menjadi bahan refleksi, wawasan, dan pengetahuan dasar kita dalam memahami sebagian persoalan politik di negara tetangga tersebut.

\section{Memahami Sekilas Masyarakat} Myanmar

Myanmar merupakan negara yang bersifat multienik, yang dihuni oleh berbagai suku kaum yang tinggal dengan beragam identitas dan budaya yang terdapat di dalamnya. Beberapa suku etnik yang ada seperti; Burma yang merupakan etnik mayoritas, disusul kemudian Chin, Kachin, Mon, Bama, Shan, Karen, Rohingya dan lain-lain yang merupakan kelompok etnik minoritas dengan corak sosial dan budaya tersendiri. Sebagian dari kelompok minoritas ini tinggal di wilayah perbatasan yang memiliki sentimen lokal atau kedaerahan yang begitu kental, sehingga secara emosional tidak memiliki keterikatan yang kuat dengan pemerintahan pusat di Rangoon. Seperti dikatakan Furnivall, corak pluralisme inilah yang menjadi ciri menonjol yang ikut mempengaruhi proses politik di negara tersebut (Furnivall 1948), yang kelak pada gilirannya mempengaruhi jalannya sejarah Myanmar yang penuh tantangan untuk tumbuh menjadi sebuah negara bangsa.

Sebagian besar masyarakat Myanmar menganut agama Budha (85\%), sementara sebagian kecil yang lain menganut agama Kristen, Protestan, Islam, Hindu, serta kepercayaan-kepercayaan animis di pedalaman. Agama Budha memiliki kedudukan istimewa dalam konteks kehidupan nasional, dan karenanya 
keyakinan terhadap agama tersebut memberikan pengaruh penting terhadap sudut pandang rakyat Myanmar dalam memahami persoalan-persoalan social maupun politik. Dalam beberapa tahun selepas kemerdekaam isu agama Budha menjadi perdebatan ideologis yang menyeruak, serta perang saudara, sehingga menimbulkan konflik yang berlarut-larut.

Sejak masa penjajahan Inggris, masyarakat Myanmar, khususnya etnik Burma, telah mengalami marjinalisasi kehidupan, baik secara politik, ekonomi, maupun sosial. Secara politik, mereka diperintah secara langsung oleh pihak Inggris dan kedaulatan mereka dirampas semenjak ditaklukkannya kerajaankerajaan lokal, khususnya dinasti Konbaung yang telah lama memerintah. Sejak tahun 1886 seluruh wilayah Myanmar dimasukkan ke dalam bagian imperium Inggris-India. Kedudukan ini berlangsung sampai dengan tahun 1937, apabila Myanmar dipisahkan dari India. Pada tahun 1942 Myanmar di bawah kekuasaan penjajah Jepang sampai dengan bulan Mei 1945. Baru kemudian di bawah kekuasaan Inggris lagi sampai dengan tahun 1948.

Sementara secara ekonomi, kedudukan mereka amat lemah, di mana penguasaan ekonomi dikendalikan oleh kaum kolonialis dan juga pendatang dari India. Sementara orang-orang pribumi sendiri kebanyakan hanyalah petani biasa dengan lahan garapan yang kurang memadai ataupun menjadi nelayan serta pengrajin kecil-kecilan. Keadaan ini menjadikan kedudukan sosial mereka juga rendah. Pada lapisan atas, lapisan pertama adalah diduduki orang-orang Inggris dan Eropa yang lain, lapisan kedua diduduki pendatang India dan elite tradisional setempat seperti: tuan tanah, pengacara, pedagang, guru, serta pegawai pemerintah. Di bagian paling bawah masyarakat terdapat mayoritas rakyat Myanmar yang terdiri dari petani, buruh, dan nelayan. Dengan melihat fakta semacam itu, nyata bahwa masyarakat Myanmar sesungguhnya merupakan masyarakat yang tereksploitasi dan amat lemah. Dalam banyak aspek, keadaan ini memunculkan ketidakpuasan di kalangan masyarakat yang berujung pada oposisi terhadap pemerintahan kolonial Inggris. Salah satu usaha perlawanan terhadap penjajah dilakukan melalui organisasi-organisasi yang sengaja dibentuk untuk mempersatukan sikap dan pandangan masyarakat dalam merespon segala kebijakan pemerintah. 
$42 \sqrt{\text { JURNAL ILMIAH MIMBAR DEMOKRASI }}$

Awal Kebangkitan dan Implikasinya

Keterlibatan kalangan mahasiswa dalam kancah politik di Myanmar (pada saat itu Burma namanya) dimulai melalui kepeloporan mereka bersama sejumlah golongan agamawan (pendeta Budha) dalam pembentukan organisasi seperti; Student Buddhist Association/Perkumpulan Mahasiswa Budha (SBA) di Rangoon pada tahun 1904, dan juga Young Men's Buddhist Association/Perkumpulan

Pemuda Budha (YMBA) pada tahun 1906. Beberapa tokoh muda yang menjadi pencetus organisasi ini adalah seperti: $\mathrm{Ba}$ Pe, Maung Gyi dan Ba Yin. Kebanyakan mereka memperoleh pendidikan Barat. Melalui organisasi-organisasi tersebut sejumlah mahasiswa mendaftarkan diri dan ikut menyebarkan nilai-nilai nasionalisme dan antikolonialisme, serta menyadarkan rakyat akan pentingnya harga diri dan kedaulatan bangsa Myanmar. Bentuk kegiatan yang mereka lakukan antara lain adalah diskusi-diskusi di Universitas Rangoon dan Sekolah Tinggi Baptis Judson di Rangoon. Di samping untuk menyuarakan pandangan organisasi, YMBA menerbitkan sejumlah publikasi seperti jurnal Burman Buddhist serta surat kabar Thuriya, yang menyokong pandangan radikal organisasi.

Namun demikian, YMBA dalam penilaian sebagian pakar, salah satunya seperti Robert Taylor misalnya, bukanlah merupakan organisasi pembaru yang betul-betul berani secara terbuka melawan pemerintah kolonial Inggris. Para pemimimpin YMBA sendiri pada hakikatnya berhaluan konservatif dan menerima penjajahan Inggris sebagai sesuatu yang tidak bisa dielakkan (Taylor 1987: 177-188). Pandangan itu boleh jadi karena ketatnya pengawasan pemerintah terhadap organisasi tersebut, sehingga mengharuskan para tokohnya untuk menyembunyikan tujuan-tujuan jangka panjang mereka. Hal ini terbukti dalam beberapa kasus yang mana YMBA menentang penggunaan sekolah sebagai tempat untuk memupuk semangat mencintai penjajah, serta keterlibatan mereka dalam insiden sepatu yang berunsur politis pada tahun 1916 yang menyebabkan sejumlah wanita Eropa diserang ketika memakai sepatu memasuki pekarangan biara.

Dalam perkembangannya, perbedaan pandangan antara golongan tua dan muda yang radikal menyebabkan YMBA pecah pada bulan September 1920. Golongan yang lebih muda, radikal, dan merupakan bagian besar dari kelompok, masuk ke dalam organisasi baru yang bernama Grand Council of Burmese Association/Perkumpulan Dewan Umum Burma (GCBA) yang menghimpun anggota dari latar belakang agama yang berbeda-beda (Steinberg 2001:11). 
Kelompok ini dipimpin oleh Tharrawaddy $\mathrm{U} \mathrm{Pu}$ sebagai ketua, dan U Chit Hlaing sebagai sekretaris. Perubahan organisasi ini memberikan ruang gerak yang lebih luas bagi kalangan muda, khususnya mahasiswa untuk melancarkan tantangan terhadap pemerintah, sehingga mulai saat itu berbagai protes secara beruntun muncul.

Salah satu puncak dari protes mahasiswa ketika itu adalah tercetusnya demonstrasi mahasiswa dan kalangan pelajar sekolah menengah pada tanggal 5 Desember tahun 1920. Pada saat itu, mahasiswa melancarkan demonstrasi menentang rancangan undang-undang yang berisi peningkatan syarat yang lebih ketat untuk mendaftar ke Universitas Rangoon. Para aktifis mahasiswa menentang rancangan tersebut, yang mereka anggap tak lebih sebagai instrumen pemerintah untuk membendung kesadaran bangsa. Pihak mahasiswa menyatakan bahwa rakyat Myanmar memerlukan suatu sekolah atau lembaga pendidikan tinggi yang berisi berbagai pengetahuan yang cocok untuk anak-anak bangsa demi masa depan mereka. Gerakan protes mahasiswa ini berlangsung di seluruh negara dan segera melibatkan sekolah-sekolah pemerintah, yang pada gilirannya mencetuskan keresahan politik yang meluas. Para pemrotes merasa prihatin bahwa Universitas Rangoon dijadikan sebagai institusi elitis yang bakal menyukarkan golongan pribumi biasa untuk memasukinya. Protes itu mendapatkan sokongan penuh dari GCBA, yang berujung usaha mereka untuk mendirikan sekolah-sekolah menengah alternatif di luar sekolah pemerintah. Pada akhirnya pemogokan tersebut membantu dalam mempercepatkan kesadaran politik dan solidaritas yang lebih besar di kalangan masyarakat Myanmar, sekaligus suatu tekanan terhadap rejim kolonial Inggris untuk memberikan konsesikonsesinya (Charney 2009:35).

Insiden di Universitas Rangoon di atas membawa implikasi terciptanya benihbenih radikalisme yang pada gilirannya akan menjadi bom waktu pada tahun-tahun selanjutnya. Salah satu tokoh penting yang kelak menjadi sumber inspirasi bagi radikalisme semacam itu adalah seorang pendeta Budha yang amat terkenal yang bernama U Ottama (1879-1939) yang dulunya juga adalah anggota GCBA. Beliau adalah seorang nasionalis yang pernah berkunjung ke Jepang dan mengajar di Universitas Otani di Kyoto dan juga ke India. Kunjungan kedua negara tersebut membawa Ottama pada pandangan perlunya modernisasi bangsa, serta perjuangan tanpa kekerasan sepertimana dilakukan Mahatma Gandhi. Tokoh lainnya adalah Hsaya San, seorang intelektual yang menjadi pemimpin 
$44 \sqrt{\text { JURNAL ILMIAH MIMBAR DEMOKRASI }}$

pemberontakan petani di pedesaan tahun 1930-1932, sehingga merebak ke seluruh wilayah negeri San serta diikuti para pemimpin masyarakat setempat, termasuk para pendeta. Hsaya San berperanan besar dalam menyebarkan pikiran-pikiran "kiri" berupa pandangan Marxisme maupun sosialis dalam perjuangan. Hal itu dilakukan San dengan menulis maupun membeli buku-buku "kiri" yang dihimpun dalam perpustakaan yang ia dirikan. Dari sinilah para mahasiswa tertarik pada ideologi radikal yang kemudian menjadi inspirasi perjuangan mereka.

Wujud radikalisme itu begitu kentara pada tahun 1930-an. Namun demikian pada dekade tersebut GCBA terpecah menjadi beberapa organisasi sempalan, di antaranya yang terkenal adalah All Burma Student Union/Gabungan Mahasiswa Seluruh Myanmar (ABSU) dan Dobama Ahsiahyone (We Burmans Association/Perkumpulan Kami Orang Burma). Dobama Ahsiahyone didirikan pada bulan Mei 1933 oleh Ba Thaoung dan kawan-kawannya setelah berlangsungnya insiden kerusuhan anti India di Rangoon. Organisasi ini merupakan persatuan politik mahasiswa yang paling besar. Bersama ABSU, Dobama Ahsiahyone merupakan organisasi mahasiswa dan pemuda yang paling berkembang pesat. Kedua duanya memiliki pucuk pimpinan yang hampir sama. Aung San yang kelak menjadi bapak pejuang kemerdekaan Myanmar, dikabarkan pernah memimpin kedua organisasi tersebut pada masa yang hampir bersamaan. Di dalam organisasi Dobama Ahsiahyone berkumpul sejumlah tokoh penting mahasiswa yang menamakan dirinya Thakin, yang berarti master/tuan, yang menggambarkan merekalah "pemilik dan penguasa sah" tanah Myanmar. Cara ini dipakai sebagai sarana untuk mengejek pihak Inggris. Slogan politik para Thakin ini adalah, "Myanmar untuk orang Myanmar" yang menekankan perlunya rakyat pribumi Myanmar memegang kekuasaan politik dan ekonomi mereka sendiri. Mereka juga memiliki dan menyanyikan lagu Dobama yang belakangan kemudian menjadi lagu kebangsaan ketika merdeka (Yi 1988:6-8).

Tokoh-tokoh mahasiswa tersebut kelak di kemudian hari akan menjadi para pemimpin utama Myanmar setelah merdeka. Mereka seperti: Aung San, U Nu, Hla Pe, Than Tun, Kwa Nyein, dan lainlain. Sebagian besar di antara tokoh-tokoh ini belajar di Universitas Rangoon dan menjadi penggerak berbagai aktifisme mahasiswa di kala itu. Maka tidaklah mengherankan jika pusat tradisi perlawanan berkembang dari universitas tersebut. Salah satu wujud dari aktifisme mahasiswa tersebut adalah munculnya organisasi Rangoon University Student Union/Persatuan Mahasiswa Universitas 
Rangoon (RUSU) pada tahun 1935 yang dipimpin oleh $\mathrm{U}$ Nu dan Aung San sebagai sekretaris jenderal. $\mathrm{Nu}$ terpilih untuk jabatan itu karena dipandang lebih senior dan matang ketimbang para mahasiswa lain yang lebih muda darinya (Yi 1988:21). Mereka secara terus menerus berusaha untuk melawan politik penjajah seraya menekankan perlunya peranan kaum pribumi. Puncak dari perlawanan politik adalah tercetusnya pemogokan besarbesaran yang dilakukan mahasiswa dan buruh di Myanmar pada akhir tahun 1930an. Insiden ini menjadi titik tolak dan modal penting dalam membangkitkan sentimen perlawanan antikolonial yang lebih mendalam. Berbagai pemogokan yang dicetuskan RUSU di bawah kepemimpinan tokoh-tokoh mahasiswa militan tersebut mencerminkan solidaritas dan kesanggupan mereka dalam memobilisasi diri tanpa adanya hambatan atau egoisme di antara para pemimpinnya. Sementara para politisi Myanmar tahun 1920-an sering berusaha untuk mempromosikan dirinya dalam menggalang solidaritas nasional, para tokoh mahasiswa justru lebih bertindak sebagai kolega ketimbang pesaing politik. Sikap baru ini memberikan sumbangan penting bagi lahirnya aliansi-aliansi berbagai kekuatan menjelang kemerdekaan Myanmar satu dekade kemudian (Charney 2009:44).
Akan tetapi sepertimana organisasi dan partai-partai politik lain, Dobama juga mengalami perpecahan tahun 1938. Masuknya sejumlah besar mahasiswa berhaluan radikal menjadi sebab utama perpecahan ini, di samping juga manajemen organisasi yang buruk serta persaingan kepemimpinan. Terdapat dua kelompok yang kemudian berusaha saling menguasai organisasi tersebut, yakni kelompok radikal (kiri) dan konservatif (kanan). Akibat perpecahan ini lahir dua kelompok Thakin, yakni satu kelompok diketuai oleh Thein Maung yang disokong oleh Kodaw Hmine, Aung San dan U Nu. Sementara satu kelompok lagi diketuai oleh Ba Sein. Pada tahun 1942, ketika Jepang menjajah Myanmar, dua kelompok ini berhasil disatukan sebentar untuk melawan Jepang melalui organisasi AntiFacist Organization yang digunakan sebagai alat propaganda melawan sekutu (Yi 1988:34). Dalam perkembangannya, selama penjajahan Jepang peranan organisasi Dobama Ahsiahyone tersisih dari arus politik utama seiring dengan kebijakan Jepang yang amat keras terhadap organisasi-organisasi politik.

Menurut Taylor peningkatan kesadaran politik mahasiswa tahun 1930an melalui organisasi-organisasi di atas dipengaruhi beberapa sebab (Taylor 1987:202-204). Pertama, karena kebencian mereka pada anggota partai politik lama 
$46 \quad \overline{\text { JURNAL ILMIAH MIMBAR DEMOKRASI }}$

yang terlalu bergantung pada sokongan dari pihak Eropa dan India, khususnya di bidang keuangan. Kedua, melalui kelompok-kelompok diskusi seperti Burma Book Club dan Nagani Club cakrawala pengetahuan mereka terhadap ideologi Marxisme dan sosialisme sebagai kritik terhadap imperialisme dan kapitalisme menjadi semakin mendalam. Ideologi Marxisme dan sosialisme dianggap memberikan kerangka baru yang lebih segar dalam perjuangan menghadapi penjajah. Ketiga, dipengaruhi oleh sikap mereka terhadap peluang pekerjaan yang terbatas karena depresi ekonomi. Banyak di antara lulusan Universitas Burma yang keluar bekerja, bersaing secara ketat dengan rekan-rekan mereka sendiri dalam berbagai bidang pekerjaan, baik di sektor pemerintah maupun swasta.

Pecahnya Perang Dunia II yang kemudian diikuti dengan masuknya tentara Jepang ke Myanmar membawa implikasi serius bagi aktifisme mahasiswa. Pihak Inggris mendesak Perdana Menteri Myanmar di masa penjajahan yakni, U Pu untuk mendeklarasikan dukungan bagi sekutu, namun Pu menolak. Di lain pihak, pada tanggal 18 November 1939 para Thakin, Organisasi Mahasiswa Seluruh Burma (All Burma Student Organization), dan Partai Sinyetha pimpinan Dr. Ba Maw membentuk Burma Freedom Bloc Organization/Organisasi Blok Pembebasan
Burma (BFBO) dengan Sekretaris Jenderal Aung San, yang bertujuan untuk menekan Inggris untuk memberikan kepastian tanggal/waktu kemerdekaan Myanmar sebagai konsesi bagi partisipasi dalam membantu pihak sekutu. BFBO sendiri merupakan koalisi dari organisasiorganisasi politik yang bertujuan memperjuangkan kemerdekaan secara penuh (Steinberg 2001:16-17). Aktifitas BFBO adalah menyelenggarakan pertemuan-pertemuan, dan melancarkan berbagai kampanye antiperang di bawah tanah dan menyatakan bahwa perang ini adalah perang antara pihak imperialis dan tak ada kaitannya dengan isu kemerdekaan Myanmar. Pemerintah kemudian meresponnya dengan menahan dan memenjarakan beberapa tokohnya, serta memaksa yang lain untuk bergerak di bawah tanah secara sembunyi-sembunyi. Dalam organisasi tersebut para tokoh mahasiswa secara bahu membahu bekerjasama menjalin aliansi dengan sejumlah tokoh politisi tua.

Sesungguhnya sebelum tentara Jepang memasuki Myanmar tahun 1941 sejumlah tokoh mahasiswa telah mengadakan kontak rahasia dengan pihak Jepang. Para tokoh mahasiswa dilatih secara kemiliteran dan diharapkan kelak dapat mengorganisir perlawanan di seluruh negara melawan Inggris. Kelompok inilah yang kemudian dikenali sebagai Komrad 
30 yang dipimpin oleh Aung San. Namun demikian, mereka bersama dengan sejumlah golongan nasionalis lain merasa kecewa dengan pemerintah Jepang yang membendung rancangan kemerdekaan Myanmar pada bulan Januari 1942, walaupun sebelumnya pihak Jepang memberi bantuan dan dukungan kuat pada golongan radikal kiri dalam melawan Inggris. Karena itu, setelah Jepang keluar dari Myanmar popularitas Aung San meningkat dengan tajam, sehingga menimbulkan kecemburan dari lawanlawan politiknya yang berujung pada pembunuhannya pada tahun 1947 menjelang kemerdekaan Myanmar (Callahan 2004:22-23). Sebagai peletak dasar berdirinya negara Myanmar Aung San dipandang memiliki jasa yang amat besar, sehingga sampai hari ini nama beliau selalu menjadi inspirasi bagi perlawanan berbagai kelompok, khususnya mahasiswa.

\section{Gerakan Mahasiswa dan Politik Setelah}

\section{Merdeka}

Gerakan mahasiswa mengalami babak baru setelah Myanmar merdeka pada bulan Januari 1948. Tempo dari tahun 1948 hingga awal 1960-an dicirikan dengan terbentuknya pemerintahan demokrasi liberal di bawah $\mathrm{U} \mathrm{Nu}$, yang terbagi dalam dua periode yakni tahun 1948-1958 dan tahun 1960-1962.
Selanjutnya pemerintahan rejim milter di bawah Jenderal $\mathrm{Ne}$ Win pasca 1962. Kedua-dua pemerintahan ini pada hakikatnya berpegang pada sosialisme. Jika dicermati secara mendalam sesungguhnya gerakan mahasiswa setelah merdeka tahun 1948 itu tidak banyak berubah meskipun pemerintahan telah berganti dari penjajah Inggris kepada pemerintahan Anti-Fascist Peoples Freedom League (AFPFL). Di kalangan mahasiswa justru muncul perpecahan yang memperlemah kedudukan mereka. Di satu pihak, sejumlah besar mahasiswa menyokong AFPFL dalam mengendalikan negara, sementara sebagian kecil yang lain menyokong Partai Komunis yang dilarang. Hal itu mudah dipahami mengingat keduadua partai tersebut didominasi sejumlah mantan tokoh penting mahasiswa di masa lalu. Kalangan mahasiswa terseret dalam polarisasi politik yang tajam. Selain itu, organisasi-organisasi mahasiswa secara internal didera oleh persaingan internal sehingga merusak proses demokrasi di kalangan mereka sendiri.

Dalam beberapa kesempatan, seperti di tahun 1949 dan 1953, dan juga sebelumnya pada tahun 1946 dan 1947, mahasiswa melakukan protes-protes dengan alasan-alasan yang sepele yang sesungguhnya bersumber dari keengganan mereka untuk belajar secara sungguhsungguh ataupun dipicu oleh peraturan- 
$48 \quad \begin{aligned} & \text { JURNAL ILMIAH MIMBAR DEMOKRASI } \\ & \text { VOLUME 13, NOMOR 2, APRIL } 2014\end{aligned}$

peraturan administratif universitas serta pemerintah yang dianggap mengurangi kebebasan mereka. Dengan kata lain, aktifisme mereka lebih banyak merupakan respon terhadap keadaan-keadaan yang bersifat biasa. Keadaan ini tentu sangat berbeda dengan demonstrasi dan mogok yang dilakukan tahun 1930-an yang begitu patriotik. Pihak pemerintah di bawah $\mathrm{U} \mathrm{Nu}$ yang sekaligus juga menjabat sebagai rektor Universitas Rangoon merasa prihatin dengan sikap mahasiswa tersebut, dan meminta mereka --dalam kondisi negara yang sudah normal-- menjaga jarak dengan politik, seraya lebih menumpukan diri pada hal-hal yang bersifat akademik untuk meningkatkan mutu lulusan dalam mengisi pembangunan. Sayangnya, himbauan $\mathrm{Nu}$ kurang memperoleh tanggapan dari mahasiswa karena mereka sudah terlalu jauh terseret dalam kemelut politik negara.

Sementara di pihak lain, pemerintahan $\mathrm{Nu}$ sendiri secara bertubitubi menghadapi tantangan yang berat dalam membangun negara. Hal itu mulai dari adanya tantangan separatis dari kelompok-kelompok minoritas, pemberontakan komunis, ketimpangan ekonomi, masalah hubungan pusat-daerah, kebobrokan birokrasi, sampai dengan perpecahan ideologi yang begitu hebat di antara pimpinan AFPFL yang memerintah akibat politik uang dan korupsi, sehingga menyebabkan kewibawaan AFPFL merosot. Wujudnya perpecahan dalam AFPFL itu menyebabkan kestabilan negara terganggu, ancaman disintegrasi, kekerasan berdarah, intervensi asing, yang mengakibatkan konflik dengan tensi tinggi mulai terlihat, sehingga mendorong $\mathrm{U} \mathrm{Nu}$ pada tanggal 24 September 1958 menyerahkan kekuasaan kepada militer di bawah Jenderal Ne Win. Ne Win kemudian membentuk pemerintahan sementara yang bertujuan menstabilkan keadaan, sampai dengan diselenggarakannya pemilihan umum (Lintner 1990:12-13). Sebagai jawaban atas kondisi tersebut, mahasiswa memprotesnya dan menganggapnya sebagai kudeta. Para mahasiswa khawatir bahwa demokrasi liberal yang diterapkan terancam oleh rejim tentara yang lambat laun akan memupus kebebasan dan membatasi ruang gerak masyarakat. Namun demikian, pihak militer meyakinkan mahasiswa bahwa pemerintahan mereka adalah pemerintahan yang menghormati demokrasi, yang semata-mata bertujuan memulihkan keadaan dan mengisi kekosongan pemerintahan, dengan membantu menegakkan otoritas semaksimal mungkin melawan kekacauan ekonomi, politik, dan lemahnya hukum (Charney 2009:94-95).

Sesudah pemilihan umum $1960 \mathrm{U} \mathrm{Nu}$ berkuasa kembali setelah partainya yang baru, yakni AFPFL-Bersih memenangi 
pertarungan. Namun, lagi-lagi $\mathrm{Nu}$ gagal membangun negara. Berbagai permasalahan muncul, mulai dari dasar pemerintahan yang memecah belahkan rakyat berkenaan dengan posisi agama Budha; masalah minoritas yang menuntut persamaan; kemerosotan ekonomi; tuntutan perlindungan undang-undang bagi pegawai pemerintah dan lain-lain. Keadaan ini mengakibatkan pihak tentara sekali lagi melancarkan kudeta pada tanggal 2 Maret 1962. Jenderal $\mathrm{Ne}$ Win kemudian membentuk Dewan Revolusioner, memberlakukan sensor atas media, koran, jurnal, film, dan penerbitan asing (Seekins 2002:7). Salah satu target utama pembatasan tersebut adalah mahasiswamahasiswa universitas yang sejak tahun 1930-an telah menjadi garda utama gerakan antikolonial serta menjadi pemasok pemimpin-pemimpin politik paling dinamis di seluruh negara dari seluruh spektrum ideologi politik tahun 1950-an.

$\mathrm{Ne}$ Win percaya bahwa ideologiideologi asing yang merasuk dalam kehidupan politik Myanmar disebabkan karena adanya kebebasan (terbukanya) politik dalam pendidikan. Karena itu pada bulan Mei 1962 Dewan Revolusioner membubarkan Dewan/Senat mahasiswa di berbagai universitas, baik di Rangoon maupun Mandalay, serta mengambil alih kewenangan mereka. Rejim kemudian melangkah lebih jauh dengan merancang program reintegrasi moral di kalangan mahasiswa dan akademisi di seluruh negara. Bentuk kegiatan itu berupa penataran dan pelatihan di seluruh negara. Menurut Ne Win demokrasi yang dipraktekkan di Myanmar selama itu memiliki banyak kepincangan sehingga gagal memberikan kesejahteraan pada rakyat. Meskipun pada awalnya tidak memperoleh tantangan secara terbuka dari rakyat karena menjanjikan kestabilan politik, namun pada gilirannya $\mathrm{Ne}$ Win menangkap dan memenjarakan semua tokoh-tokoh politik, termasuk U Nu. Kelak pada tahun 1965 tentara juga melarang semua partai politik kecuali Burma Socialist Program Party (BSPP) yang dikuasai bekas tentara dan polisi. Tantangan yang datang justru dari kalangan mahasiswa.

Pada bulan Juli 1962 mahasiswa secara terbuka berdemonstrasi menentang rejim baru itu yang dianggap tidak konstitusional. Tindakan itu dibalas oleh pihak tentara dengan menyerang kampus Universitas Rangoon lalu meledakkan bangunan Rangoon University Student Union (RUSU) yang telah menjadi simbol kebanggaan mahasiswa sejak tahun 1930an. Bangunan itu merupakan situs titik awal perjuangan kaum nasionalis Myanmar yang dikaitkan secara erat dengan Aung San bapak kemerdekaan negara itu 
(Charney 2009:116). Penghancuran gedung dilakukan $\mathrm{Ne}$ Win sebagai cara untuk memberikan pesan bahwa pihak militer tidak pernah ragu-ragu menumpas para pembangkang. Di samping itu pihak militer ingin membangun simbolisme baru dengan memupus ingatan umum terhadap perjuangan kaum nasionalis sipil Myanmar yang bermula dari tempat tersebut. Namun demikian, seperti tampak dalam tahuntahun berikutnya, baik pada pertengahan tahun 1970-an maupun akhir 1980-an, bahwa penghancuran bangunan RUSU tidaklah dapat mengakhiri aktifisme politik mahasiswa.

Dalam serangan tersebut puluhan mahasiswa menjadi korban, kurang lebih antara 60-100 orang meninggal. Pemerintah kemudian mengenakan berbagai pembatasan kepada gerakan mahasiswa termasuk yang berkaitan dengan kehidupan di kampus, berorganisasi, dan berpolitik kecuali melalui BSPP. Sebarang bentuk pelanggaran terhadap peraturan ini akan menghadapi resiko tinggi, termasuk dikeluarkan dari universitas ataupun dipenjara. Akibatnya gerakan mahasiswa menjadi kendur, karena banyak mahasiswa yang tidak berminat dalam politik dan lebih menumpukan pada kegiatan-kegiatan belajar di kampus. Keadaaan ini mirip dengan yang wujud di sejumlah negara di Asia Tenggara, termasuk Indonesia di kemudian hari. Sebagian besar para mahasiswa kemudian lebih mengalihkan pada aktifitas yang bersifat rutin seperti kuliah, rekreasi, maupun hobby, seperti menonton film, camping dan sejenisnya. Mereka berharap dapat lulus tepat waktu dan mendapat pekerjaan selepas tamat, termasuklah menjadi tentara jika perlu.

Namun demikian ada sejumlah kecil mahasiswa yang tetap menjaga idealisme yang berminat dengan politik. Mereka menjadi anggota BSPP, menghidupkan tradisi tahun 1930-an yang tetap menjadi kebanggaan mahasiswa, serta juga terlibat menjalin komunikasi secara rahasia dengan organisasi-organisasi terlarang. Kelompok ini secara konsisten menyebarkan pandangan tentang perjuangan mahasiswa di masa lalu kepada mahasiswa-mahasiswa baru untuk dijadikan ilham atau sumber inspirasi. Mereka juga tidak segan-segan menyebarkan bacaan-bacaan yang berisi ideologi Marxisme serta ideologi revolusioner dunia yang lain agar diminati mahasiswa, sekaligus sebagai alat untuk menolak propaganda ideologi negara yang dianggap gagal. Para aktifis ini tidak segan-segan menjadikan peringatan harihari tertentu sebagai momentum untuk berkumpul melakukan penentangan/protes terhadap pemerintah meskipun menghadapi resiko yang berat (Aye Saung 1989). 
Di Bawah Kekuasaan Rejim Militer

Pada tahun 1970-an gerakan mahasiswa di Myanmar muncul dalam beberapa kali kesempatan. Tahun 19741975 merupakan masa yang amat krusial bagi rejim militer karena mereka dihadapkan pada demontrasi dan mogok mahasiswa dan buruh yang berujung kerusuhan. Menjelang April 1974 pemerintah menyadari bahwa mayoritas pekerja telah mengalami demoralisasi dan kemarahan sebagai hasil dari naiknya harga-harga beras dan berbagai komoditas dasar lainnya. Pada bulan Mei 1974 misalnya meletus pemogokan buruh industri minyak, buruh kereta api, tekstil dan pelabuhan yang menentang rejim karena kekurangan bahan keperluan harian, serta naiknya harga-harga barang yang mengakibatkan kondisi kehidupan buruh memburuk. Demontrasi ini memperoleh sokongan kuat dari elemen-elemen mahasiswa. Sebagai jawabannya Jenderal $\mathrm{Ne}$ Win bertindak cepat dengan menumpas aksi pembangkangan tersebut. Akibatnya sebanyak 28 orang meninggal, sementara 80 orang lagi luka-luka.

Pada bulan Desember 1974, para mahasiswa universitas di Rangoon melakukan tindakan demonstrasi memprotes perlakuan pemerintah yang dianggap kurang patut terhadap jenazah almarhum U Thant, bekas Sekretaris Jenderal PBB (Perserikatan Bangsa-
Bangsa) yang meninggal dan akan dimakamkan di Myanmar. Almarhum U Thant merupakan simbol dari rejim sipil era demokrasi liberal pra 1962, yang meninggal karena penyakit kanker di New York pada bulan November 1974. Kepulangan jenazahnya ke Rangoon memberikan suatu katalisator bagi masyarakat untuk melepas frustasi dari berbagai problem ekonomi yang dihadapi Myanmar. Dalam upacara pemakaman yang dihadiri sekitar 50.000 pelayat, mahasiswa mengambil jenazahnya dan meletakkannya di Rangoon University Convocation Hall. Mahasiswa bersama para biksu Budha kemudian berusaha memakamkan di dekat situs gedung RUSU yang telah dihancurkan tahun 1962. Namun pemerintah melarangnya dan akan mengambil jenazah tersebut. Pemerintah kemudian menutup lembaga-lembaga universitas dan memutus komunikasi internasional dengan beberapa negara. Pada tanggal 11 Desember, 1000 tentara dan polisi menduduki kampus dan secara paksa mengambil jenazah dan merusak taman yang dibangun di tempat pemakaman oleh keluarga mendiang $\mathrm{U}$ Thant (Charney 2009:137).

Mahasiswa, para pemuda dan juga sebagian bhiksu kemudian melancarkan protes-protes di seluruh Rangoon dengan menyerang tentara dan polisi. Dikabarkan bahwa para pemrotes merusak kantor- 
52 JURNAL ILMIAH MIMBAR DEMOKRASI

kantor polisi, menghancurkan bangunan perusahaan transport milik pemerintah serta membakar mobil-mobil di dalamnya, dan menghancurkan kereta api di satu stasiun lokal. Kejadian itu dapat diakhiri dengan tindakan keras, yang mengakibatkan sekurang-kurangnya 4000 orang ditahan. Polisi juga menembak mati 9 pemrotes dan melukai 74 orang. Undangundang darurat diberlakukan pada hari tersebut di seluruh wilayah Rangoon. Pemerintah kemudian juga membentuk mahkamah khusus untuk mengadili para pemrotes. Setelah kerusuhan tersebut pemerintah menutup universitasuniversitas di wilayah Mandalay dan Rangoon selama 4 bulan (Carney 2009:138).

Mahasiswa justru tidak gentar dengan tindakan itu. Pada tahun berikutnya mereka dengan berani melancarkan protesprotesnya menuntut pemerintah untuk mengambil langkah-langkah yang cepat dalam menyelamatkan ekonomi negara. Pada tanggal 6 Juni 1975 misalnya, mahasiswa-mahasiswa Institute of Economy menyerukan pemogokan dan boikot. Mereka kemudian berarak di berbagai kampus, termasuk Rangoon Institute of Technology (RIT) dan Rangoon University (RU), dan lain-lain, menyerukan perbaikan ekonomi negara serta pembebasan para mahasiswa dan buruh yang masih ditahan dalam kerusuhan bulan Desember 1974. Dalam beberapa hari berikutnya 500 orang pemrotes bergerak dari Rangoon University ke Jalan Sule Pagoda dan ke pusat kota Rangoon. Pada saat itu jumlah mereka sudah membludak menjadi 3000 orang dan mengarak serta membakar patung Ne Win dan San Yu di monumen kemerdekaan. Para mahasiswa menuntut agar pemerintahan militer diakhiri, kenaikan harga-harga dan pengangguran diatasi, seraya menuntut kebebasan dalam berorganisasi. Demonstrasi kemudian berlanjut di ibukota dan mahasiswa mendirikan camp di Pagoda Shwedagon. Pemerintah merespon protes tersebut dengan mengirim tentara dan tank-tank, menahan mahasiswa, serta melarang demonstrasi-demonstrasi lanjutan. Pada gilirannya pemerintah juga menutup kembali beberapa universitas pada bulan Juni 1975, setelah dibuka sebelumnya di bulan Januari (Charney 2009:139).

Tidak berhenti sampai di situ, pada bulan Maret 1976 para mahasiswa di Rangoon melakukan protes-protesnya lagi berkenaan dengan ulang tahun ke 100 atas kelahiran Thakin Kodaw Himne, salah satu tokoh Dobama Ahsiahyone di masa lalu. Aksi tersebut ditindak pemerintah dengan keras yang menyebabkan banyak di antara mahasiswa yang ditangkap, sementara sebagian lagi yang lain banyak yang melarikan diri ke wilayah perbatasan 
Myanmar-Thailand, mencari perlindungan serta terlibat dalam perjuangan bersenjata melawan pemerintah. Secara umum, munculnya aksi-aksi protes tersebut lebih disebabkan oleh persoalan ekonomi, di mana pemerintah dianggap gagal memperbaiki ekonomi negara serta mengangkat kesejahteraan rakyat (Lintner 1990:28). Meskipun berkali-kali pemerintah melakukan tindakan represif untuk membendung gerakan-gerakan mahasiswa, namun pada kenyataannya gerakan mahasiswa masih tetap saja muncul. Bahkan pada tahap tertentu mereka mampu membangun kerjasama dan kontak-kontak dengan kelompok buruh dan juga para rahib Budha ataupun elemenelemen bekas tentara yang tidakpuas dengan cara-cara rejim dalam memerintah.

Pada tahun 1980-an misalnya, muncul kegelisahan yang semakin meningkat di kalangan mahasiswa atas kondisi negara yang memprihatinkan yang ditandai dengan meningkatnya pengangguran, rendahnya pertumbuhan ekonomi, meningkatnya kadar kemiskinan, korupsi yang merebak di kalangan pejabat, nepotisme yang memihak golongan atas, meluasnya penyelundupan, serta kegagalan pemerintah dalam menyediakan kebutuhan pokok sehari-hari. Kondisi ini mendorong lahirnya sejumlah protes yang melibatkan mahasiswa, buruh, dan para rahib Budha.
Fenomena tersebut seolah menjadi warning bagi pemerintah untuk selalu waspada.

Seperti yang terjadi pada tahun 1987 , karena kesalahan pengelolaan negara menyebabkan ekonomi Myanmar merosot tajam. Salah satu langkah yang tidak popular adalah melakukan pemotongan nilai mata uang Kyat, di mana pemerintah menghapus begitu saja tabungan masyarakat dengan menerapkan kebijakan perubahan mata uang secara tiba-tiba (demonetization), yang menyebabkan kerusuhan besar di seluruh negara (Maung 1999:6-8). Keadaan ini mendorong mahasiswa turun ke jalan pada bulan Maret 1988 melakukan demonstrasi selama satu minggu. Tentara kemudian mengambil tindakan keras sehingga beberapa mahasiswa meninggal, ratusan lainnya dikabarkan cedera dan puluhan diantaranya dijebloskan ke dalam penjara. Dua bulan kemudian para mahasiswa memprotes larangan pemerintah untuk mengadakan upacara peringatan bagi rekan-rekan mereka yang tewas sebelumnya. Pada tanggal 16 Juni mahasiswa Rangoon Arts and Sciences University (RASU) membacakan tuntutan mereka pada pemerintah agar membebaskan 1500 mahasiswa yang dipenjara, seraya memberikan mereka kebebasan untuk berorganisasi. 
Ketika tuntutan mereka tidak dikabulkan, maka sekitar 5000 mahasiswa Rangoon Institute of Technology (RIT) dan dua sekolah tinggi kedokteran memboikot kelas dan melancarkan protes. Terjadi bentrokan besar dengan polisi. Penduduk menunjukkan simpatinya dengan membantu mahasiswa. Tuntutan mahasiswa kemudian bergeser dari protes ekonomi menjadi tuntutan yang lebih bersifat politik seperti meminta kebebasan untuk mendirikan organisasi persatuan mahasiswa yang independen. Di samping itu, mereka juga menuntut adanya perubahan sistem politik ynng memberi ruang kebebasan serta kemajuan ekonomi. Tuntutan ini secara otomatis merupakan bagian dari kampanye anti Ne Win yang secara tidak langsung juga memperoleh dukungan dari lawan-lawan politiknya, khususnya para jenderal yang disingkirkan Ne Win. Mereka seperti Aung Gyi, salah seorang tokoh kudeta pada tahun 1962, dan juga Tin U, mantan Menteri Pertahanan yang pernah dipenjara Ne Win. Kehadiran para mantan tokoh-tokoh pemerintahan itu menyemarakkan kekuatan antipemerintah.

Adanya tekanan yang bertubi-tubi akibat kemerosotan ekonomi negara dan konflik domestik, pada bulan Juli 1988 dalam Konggres BSPP Jenderal Ne Win mengakui berbagai kesalahan dalam kebijakan ekonomi yang diterapkannya dan menganggapnya sebagai eksperimen yang gagal. Ia kemudian mundur dan digantikan oleh Jenderal Sein Lwin sebagai ketua BSPP sekaligus presiden Myanmar yang baru. Sein Lwin memiliki reputasi sebagai tokoh garis keras yang ikut menumpas gerakan mahasiswa dalam insiden "Jembatan Putih" yang menumpas gerakan mahasiswa secara brutal pada bulan Juli 1962 (Seekins 2002:82). Sebagai respon atas perkembangan tersebut, para aktifis mahasiswa kemudian melancarkan protes jalanan menuju Pagoda Shwedagon dan menyebarkan pamflet-pamflet yang menyatakan Sein Lwin sebagai "penyembelih dari Rangoon" seraya menyerukan diadakannya pemogokan umum menuntut dipulihkannya demokrasi serta pemilihan umum multipartai.

Demonstrasi itu juga diikuti oleh para bhiksu, sehingga berkembang sedemikian rupa menjadi protes-protes umum yang meluas. Alih-alih mengambil jalan dialog, Sein Lwin justru bersikeras akan menghentikan demonstrasi dengan cara apapun, termasuk dengan menerapkan keadaan darurat di Rangoon. Namun demonstrasi telah menyebar dengan cepat ke kota-kota lain di hampir seluruh negara. Pada tanggal 8 Agustus 1988 demonstrasi mencapai puncaknya yang melibatkan sedikitnya satu juta warga Myanmar turun ke jalanan. Para demonstran bergerak di Rangoon membakar bus, merusak gedunggedung pemerintah serta fasilitas umum 
lainnya. Pemerintah kemudian bertindak keras menumpasnya di tengah kecaman masyarakat internasional. Dikabarkan tidak kurang dari 3000 orang telah terbunuh di wilayah Rangoon saja. Peristiwa itu dikenal dengan insiden 8.8.888 (Maung 1999:32-33).

Akibat insiden tersebut Sein Lwin mengundurkan diri dari jabatannya sebagai presiden BSPP dan presiden Myanmar. Kedudukannya digantikan oleh Dr. Maung-Maung. Di bawah beliau, pemerintah berusaha mengakomodasi beberapa tuntutan para pemrotes termasuk mahasiswa dengan memberikan beberapa konsesi kelonggaran, seperti kebebasan menerbitkan surat kabar, jurnal, majalah, liberalisasi sektor swasta. Diperbolehkannya swasta dalam mengelola bisnis hiburan umum, seperti film, bioskop, dan lain-lain (Seekins 2002:96). Namun demikian, para demonstran tetap tidak puas mengingat kedekatan MaungMaung dengan Ne Win. Para demonstran menuntut Maung-Maung mundur. Situasi internal dalam negara yang semakin kalut, dan perpecahan yang melanda BSPP menyebabkan ancaman disintegrasi di depan mata. Akibatnya pada tanggal 18 September 1988 seorang kawan dekat Ne Win, yakni Jenderal Saw Maung melancarkan kudeta, memecat MaungMaung dan pemerintahan BSPP, menertibkan keadaan, memerintahkan pegawai negeri bekerja seperti semula, memblokade jalan-jalan, melarang orang berkumpul lebih dari 5 orang, membersihkan jalan-jalan dari barikade, dan membubarkan pusat-pusat demonstrasi serta menembak mati mahasiswa yang melawan. Pada tanggal 26 September junta mendirikan State Law and Order Restoration Council/Dewan Pemulihan Ketertiban dan Hukum Negara (SLORC) di bawah pimpinan Jenderal Saw Maung (Callahan 2004:106).

Menanggapi kudeta Saw Maung tersebut ribuan mahasiswa mengalir ke wilayah perbatasan Myanmar-Thailand. Sebagian besar di antara mereka bergabung dengan kelompok-kelompok perlawanan etnik bersenjata di perbatasan dan memperoleh perlindungan dari komunitaskomunitas di wilayah tersebut. Jumlah mereka diperkirakan mencapai ribuan orang. Mereka bergabung dalam campcamp militer kelompok seperti Karen National Union (KNU) dan Burma Communist Party (BCP) serta mendapatkan pelatihan bersenjata maupun taktik perang gerilya. Sebagai gambaran, di kamp KNU sendiri terdapat 2000 orang mahasiswa. Tujuan mereka adalah sama, yakni menggulingkan pemerintahan di Rangoon secara bersama-sama. Dalam pengungsian itu mahasiswa mendirikan All Burma Students Democratic Front (ABSDF) yang menjadi payung organisasi 
mahasiswa untuk melawan rejim. Untuk menghadapi ancaman itu, rejim SLORC mengeluarkan program amnesti agar mahasiswa kembali ke rumah dan keluarga mereka masing-masing. Himbauan tersebut disampaikan melalui televisi, radio, papan pengumuman, pamflet-pamflet yang disebarkan dari udara. Pemerintah menyerukan mahasiswa agar tidak dimanfaatkan oleh kaum pemberontak yang pada akhirnya mencabik-cabik Myanmar dalam konflik berkepanjangan. Himbauan pemerintah itu cukup efektif sehingga sebagian besar di antara mahasiswa pada awal 1989 telah kembali (Charney 2009:163).

Bersamaan dengan keberhasilan pemulangan mahasiswa di atas, pemerintah kemudian menggenapinya dengan melanjutkan kebijakan "pengendalian" mahasiswa dengan mengambil sejumlah langkah penting. Di antaranya adalah dengan melancarkan program penataran di seluruh negara bagi guru, dosen, mahasiswa, sebagai "kursus penyegaran" dan pembentukan mental dengan menanamkan nilai-nilai dasar negara, sejarah peranan militer, sejarah bangsa, kebijakan dan haluan ekonomi, hukum serta undang-undang negara. Kampanye ini mirip dengan pola pendidikan P4 (Pedoman, Penghayatan, dan Pengamalan Pancasila) yang pernah diterapkan di Indonesia. Di mata rejim, kampus dan mahasiswa harus dikendalikan dengan ketat dan dosen harus lebih bertanggungjawab dalam mendidik mahasiswanya agar berperilaku "baik" sesuai dengan apa yang dikehendaki negara. Mereka menganggap bahwa perilaku demonstrasi mahasiswa yang buruk selama ini banyak dipengaruhi oleh elemen-elemen subversif, baik dari luar maupun dalam negeri, yakni kepentingan kelompok-kelompok tertentu yang memanfaatkan kampus sebagai area keresahan. Mereka seperti kelompokkelompok oposisi maupun politisi-politisi oportunis dalam negara. Di bawah rejim kuku besi SLORC militer terus berusaha menancapkan kekuasaannya.

Meskipun menjanjikan berbagai pembaruan poltik dan ekonomi pada kenyataannya rejim SLORC tidak bergeming dari cara-cara represif dan otoriter. Tantangan bukan hanya datang dari mahasiswa tetapi juga kelompokkelompok masyarakat umum, khususnya kubu oposisi di bawah pimpinan Aung San Suu Kyi, puteri mendiang Aung San, dengan partainya National League for Democracy (NLD) yang didirikan pada bulan September 1988. Jika dikaji lebih jauh, penerapan kebijakan "serampang dua mata" di atas merupakan bagian dari indoktrinasi menyeluruh yang dilakukan rejim untuk menancapkan hegemoninya di kalangan mahasiswa. Hasil yang dicapai 
dari kebijakan ini dalam jangka pendek memang cukup ampuh dalam membendung gerakan perlawanan. Terbukti bahwa selama dekade 1990-an sampai dekade tahun 2000-an tidak ada gerakan perlawanan yang menonjol yang datang dari mahasiswa maupun oposisi, yang secara signifikan mampu menggoyahkan kedudukan rejim.

\section{Menuju Haluan Baru: Antara Realita dan Kosmetika}

Insiden perlawanan secara terbuka yang menonjol baru muncul pada bulan Agustus 2007 yang dipicu oleh kenaikan harga kebutuhan pokok sehari-hari, seperti; makanan, minuman, tepung, minyak goreng, dan lain-lain, yang kemudian ditambah dengan kenaikan harga bahan bakar minyak (BBM). Keadaan itu menambah beban kehidupan rakyat sehingga mencetuskan demonstrasi hingga bulan September di sejumlah tempat. Sebagian kelompok-kelompok mahasiswa terlibat dalam gerakan penentangan tersebut dan secara aktif berusaha menjalin kontak-kontak dengan kelompokkelompok buruh dan juga oposisi. Pemerintah merespon dengan cara keras, dengan menumpas pemberontakan tersebut dan menahan para pemrotes. Yakin bahwa tentara tidak dapat memadamkan sebarang pemrotes dari masyarakat umum, dalam bulan September para pendeta Budha melancarkan protes-protesnya di wilayah Tenggara Myanmar melawan kebijakan ekonomi pemerintah. Protes ini kemudian menyebar ke seluruh negara diikuti ribuan pendeta.

Akibatnya pada tanggal 26 September militer bertindak keras dengan menembak, menginterogasi, dan menahan para pendeta. Sejumlah orang diseret ke pengadilan dan dijebloskan ke dalam penjara. Langkah itu diikuti dengan pemblokiran telepon genggam, email, akses internet, dan komunikasi melalui pos. Dalam pengadilan yang digelar sepanjang tahun 2008 tidak kurang dari 70 orang lebih yang dijatuhi hukuman mulai dari 2,5 tahun hingga 65 tahun penjara. Mereka adalah aktivis mahasiswa, penulis, musisi, biksu, anggota partai oposisi Liga Nasional untuk Demokrasi (LND), dan tokoh-tokoh pro demokrasi lainnya. Para tahanan ini disebar ke sejumlah penjara di seluruh Myanmar secara berpindah-pindah dan diisolasi dari dunia luar. Peristiwa 26 September tersebut dikenal sebagai Revolusi Kunyit yang amat mengguncang pemerintah. Kejadian ini membawa implikasi secara internal di tubuh rejim (Charney 2009:196-197).

Pada bulan November 2007 tanpa hiruk pikuk dan sebab-sebab yang begitu jelas SLORC dibubarkan dan digantikan dengan State Peace and Development Council (SPDC). Kejadian itu dilakukan 
menyongsong masuknya Myanmar ke dalam keanggotaan ASEAN. Hal ini sebagai bagian dari cara mereka untuk mengakomodasi aspirasi masyarakat internasional yang menyorot perilaku rejim. Namun banyak ahli yang menyebut hal ini sebagai langkah "setengah hati" ketimbang sebagai suatu perubahan mendasar. Dua lembaga tersebut berbeda nama saja, tapi pada hakikatnya sama dan serupa. Mahasiswa menanggapi perubahan itu dengan nada curiga dan menganggapnya sebagai upaya rejim menutupi wajah bopeng kekuasaan yang semakin tidak kompeten.

Namun seiring dengan munculnya tekanan dari masyarakat internasional dan juga kebutuhan akomodasi sebagai anggota ASEAN, Myanmar secara perlahan-lahan mulai membuka diri. Hal itu dibuktikan dengan beberapa kebijakan politik dan pembaruan yang dilancarkan rejim beberapa tahun belakangan seperti: Menyelenggarakan pemilu pada 7 November tahun 2010 yang dimenangi partai dukungan pemerintah, yakni USDP (Partai Uni Solidaritas dan Pembangunan); dibubarkannya pemerintahan SPDC pimpinan Jenderal Than Shwe digantikan dengan pemerintahan sipil Jenderal (Purn.) Thein Sein pada tanggal 30 Maret 2010; mengijinkan Aung San Suu Kyi ke luar negeri untuk menerima hadiah Nobel Perdamaian; pembebasan ratusan tahanan politik; kebebasan unjuk rasa bagi buruh; penyingkiran sejumlah tokoh non reformis termasuk wakil presiden Tin Aung Myint Oo pada Juli 2012; serta penghapusan larangan berkumpul lebih dari 5 orang, dan lain-lain.

Meskipun demikian, banyak kalangan menilai hal ini sebagai perubahan kosmetik belaka, dan hanya ingin "mengambil hati" masyarakat internasional. Hakikatnya militer di bawah kendali tokoh lama yakni, Jenderal Than Shwe tetap memainkan peranan di balik layar dalam panggung politik. Selain itu, di banyak tempat kebebasan yang ada masih dibatasi. Salah satu contohnya adalah insiden buruk yang terjadi dua tahun lalu, yakni ketika pada bulan Juli 2012 para mahasiswa melancarkan demonstrasi memperingati 50 tahun aksi brutal militer yang terjadi pada tahun 1962 ketika Jenderal $\mathrm{Ne}$ Win melancarkan kudeta. Akibat insiden tersebut puluhan mahasiswa ditangkap selama beberapa hari dan kemudian dilepaskan. Hal tersebut memicu kekhawatiran akan arah reformasi yang ditempuh oleh pemerintahan baru Myanmar. Apalagi belakangan sikap intoleransi militer tetap nampak sehingga memancing berbagai pertumpahan bersenjata dengan kelompok-kelompok etnis minoritas yang memberontak, serta juga munculnya konflik-konflik komunal yang sukar dibendung. Dalam konteks 
seperti itu, akankah gerakan mahasiswa mampu menjadi salah satu simpul kekuatan yang dapat mendorong terjadinya perubahan? Jawaban itu tergantung pada sejauh mana kekuatan mahasiswa dan kelompok-kelompok di luar pemerintah bersatu melampaui batas-batas kesadaran internal dan visi mereka selama ini.

\section{Kesimpulan}

Berdasarkan uraian di atas dapat dikemukakan bahwa gerakan mahasiswa di Myanmar tidak pernah terlepas dari kemelut politik di negara tersebut. Berbagai isu politik yang muncul seringkali menjadi pemicu yang turut melempangkan jalan bagi munculnya aktifisme mahasiswa. Sikap dan respon mereka atas berbagai persoalan bangsa menjadi barometer terhadap tingkat kepuasan masyarakat terhadap situasi yang berkembang. Karena bagaimanapun reaksi mahasiswa pada umumnya mencerminkan sebagian aspirasi dalam masyarakat. Dalam konteks masyarakat Myanmar, sikap kepedulian mahasiswa ditunjukkan mulai dari sejak jaman sebelum kemerdekaan sampai dengan hari ini. Di masa lalu keterlibatan tokoh-tokoh mahasiswa dalam berbagai organisasi memberikan kontribusi penting bagi munculnya gerakan-gerakan anti kolonial, yang kemudian berpuncak pada kemerdekaan pada tahun 1948. Bersama para politisi yang lebih senior, kalangan mahasiswa ikut menanamkan kesadaran nilai-nilai kebangsaan serta harga diri bangsa Myanmar.

Sesudah merdeka gerakan mahasiswa muncul sebagai kekuatan moral yang turut mengkoreksi kebijakan pemerintah, mulai dari masa pemerintahan demokrasi liberal U Nu tahun 1948-1958, 1960-1962, dan kemudian di bawah rejim militer 19581960, 1962-2011, sampai kemudian di bawah pemerintahan kuasi militer hari ini. Adanya perbedaan visi antara mahasiswa dengan rejim menyebabkan gerakan mereka berbenturan dengan kekuasaan, yang kemudian berujung pada penumpasan pada tahun 1958, 1962, 1974, 1975, 1988. Seperti ditunjukkan sejarah, episode gerakan mahasiswa di Myanmar mengalami tantangan yang amat berat sekaligus heroik. Hal tersebut mulai dari represi rejim yang begitu keras, perpecahan internal mengikuti garis-garis etnik, perebutan kepemimpinan, perbedaan ideologi dan kelompok, orientasi gerakan, sampai dengan keterlibatan mereka dengan kelompok-kelompok separatis bersenjata di perbatasan, yang menyebabkan gerakan mereka turut menjadi "sumbu" dalam pergolakan politik di Myanmar. Meskipun sampai sejauh ini, gerakan mahasiswa belum bisa benar-benar bersatu dengan kuat sebagai satu barisan yang mampu menantang rejim secara serius, namun 
gerakan mereka cukup memberikan tekanan pada rejim. Apalagi dalam beberapa kesempatan mereka juga menjalin aliansi dengan segmen kelompok masyarakat yang lain, seperti kelompok buruh, intelektual, aktifis pro demokrasi, para desiden rejim yang kecewa, serta lembaga swadaya masyarakat, sehingga pada tahap tertentu dapat menambah energi bagi suatu perjuangan panjang di masa depan.

\section{DAFTAR PUSTAKA}

Altbach, Philip G., "Gerakan Mahasiswa Dalam Dasawarsa Tujuh Puluh Dan Delapan Puluhan", dalam Philip G. Altbach (ed.), Politik Dan Mahasiswa: Perspektif dan Kecenderungan Masa Kini, (Terj.), Jakarta: PT Gramedia, 1988:1-18.

Callahan, Mary P., Making Enemies: War and State Building in Burma, Singapore: Singapore University Press, 2004.

Charney, Michael W., A History of Modern Burma, Cambridge: Cambridge University Press, 2009.
Furnivall, J.S., Colonial Policy and Practice: A Comparative Study of Burma and Netherlands India, Cambridge: Cambridge University Pres, 1948.

Lintner, Bertil, Outrage: Burma's Struggle for Democracy, London: White Lotus, 1990.

Maung Maung, The 1988 Uprising in Burma, New Haven, CT: Yale University Southeast Asia Studies, 1999.

Saung, Aye, Burma in the Back Row: Autobiography of a Burman Rebel, Hongkong: Asia 2000 Ltd., 1989.

Seekins, Donald M., The Disorder of Order: The Army State in Burma Since 1962, Bangkok: White Lotus, 2002.

Smith, Martin, Burma: Insurgency and the Politics of Ethnicity, London: Zed Books, 1999.

Steinberg, David I., Burma: The State of Myanmar, Washington, DC: Georgetown University Press, 2001.

Taylor, Robert, The State in Burma, London: C. Hurst, 1987.

Yi, Khin, The Dobama Movement in Burma (1930-1938), Ithaca: Cornell University, Southeast Asia Program Monograph, 1988. 